\title{
Amprenta modelelor străine în secțiunea de morfologie a gramaticii lui Ioan Piuariu-Molnar (Deutsch-Walachische Sprachlehre, Viena, 1788)
}

\author{
Ana-Maria Minuț, Ion Lihaciu* \\ Facultatea de Litere, Universitatea „Alexandru Ioan Cuza”, Bd. Carol I 11, 700506 Iaşi, România
}

\section{Despre articol}

Istoric:

Primit 14 ianuarie 2018

Acceptat 18 februarie 2018

Publicat 27 aprilie 2018

Cuvinte-cheie:

diacronie

contact lingvistic

gramatică istorică

\begin{abstract}
Rezumat
Una din etapele pe care le-am parcurs în procesul de editare a gramaticii germanoromâne a lui Ioan Piuariu-Molnar a constat în identificarea modelelor urmate de autor. În literatura de specialitate este larg răspîndită afirmația că gramatica lui Molnar a avut ca model gramatica lui Samuil Micu și Gheorge Șincai, Elementa lingue daco-romane sive valachice (Viena, 1780). Am constatat că, în cazul unor capitole ale gramaticii, se confirmă, în mod clar, influența acestui model. Există însă și capitole diferite de cele corespunzătoare din Elementa sau capitole care figurează doar în gramatica lui Molnar, nu și în cea a lui Micu și Șincai. Faptul se explică prin aceea că Molnar a urmat și modelul unor gramatici străine, care au avut în epocă un mare succes și o circulație intensă; este vorba de două gramatici ale limbii franceze, scrise în limba germană, cu terminologie gramaticală latinească: lucrarea lui J.R. des Pepliers, Nouvelle et parfaite grammaire royale françoise et allemande. Neue und vollständige königliche französische Grammatik, bisher unter dem Nahmen des Herrn der Pepliers vielmals herausgegeben (Leipzig, 1765, Tipografia M.G. Weidmanns Erben und Reich), respectiv gramatica lui Hilmar Curas, Erleichterte und durch lange Erfahrung verbesserte französische Grammatik (Berlin, 1759, Tipografia lui Friedrich Nicolai). In prezentul articol am relevat capitolele de morfologie în care este recognoscibilă influența gramaticilor lui Pepliers și Curas. Influența modelelor străine se reflectă în: organizarea internă a capitolelor, terminologia utilizată şi corespondentele în limba germană ale cuvintelor; în privința ultimului aspect, am evidențiat, în studiul nostru, cazurile în care echivalentele germane indicate de Molnar pentru cuvintele românești sînt identice cu echivalentele germane indicate în gramatica lui Pepliers sau în cea a lui Curas pentru cuvintele din limba franceză.
\end{abstract}

\section{Preambul}

Faimos printre contemporani grație, în primul rînd, carierei sale exemplare de „medic oculist al Marelui Principat al Transilvaniei”, Ioan Piuariu-Molnar (1749, Sadu [județul Sibiu] - 1815, Sibiu) se înscrie, totodată, în seria de intelectuali ardeleni implicați, începînd din a doua jumătate a secolului al XVIIIlea, în modernizarea, după model occidental, a societății românești. „Atitudinea pragmatică” (Niculescu, 1978, p. 59) a cărturarilor ardeleni, pe deplin adaptată la realitățile politice, sociale, culturale ale timpului se concretizează, pe de o parte, în elaborarea de gramatici și dicționare, care aveau rolul de a face din româna literară un instrument de comunicare perfecționat, unitar din punct de vedere fonetic și gramatical și cu un lexic corespunzător; pe de altă parte, iluminiștii ardeleni au meritul fundamental de a fi inițiat acțiuni organizate de difuzare, prin lucrările lor teoretice și practice, traduceri și originale (din domeniul istoriei, filosofiei, retoricii, teologiei, matematicii, științelor naturale, medicinei, geografiei, fizicii, chimiei, agronomiei), a științei și culturii Occidentului.

\footnotetext{
*Adrese de corespondență:a_minut@hotmail.com (AMM), lihaciu@uaic.ro(IL).
} 
Ana-Maria Minuț, Ion Lihaciu

În limitele aceluiași crez se înscrie și Ioan Piuariu-Molnar, care, ca ,agent”” (în sensul doctrinei lui Pierre Bourdieu) al mai multor „cîmpuri” social determinate s-a afirmat atît ca autor al unei gramatici germanoromâne (Deutsch-Walachische Sprachlehre, Viena, 1788; Sibiu, 1810; Sibiu, 1823), cît și al unui dicționar german-român (Wörterbüchlein deutsch und wallachisches, Sibiu, 1822) și al primei cărți de economie rurală (Economia stupilor, Viena, 1785; Sibiu, 1808), ca editor ${ }^{1}$ al unei retorici (Retorică, adecă învățătura și întocmirea frumoasei cuvîntări. Acum întăi izvodită pe limba românească. Impodobită și întemeiată cu pildele vechilor filosofi și dascali bisericești, Buda, 1798) și ca traducător ${ }^{2}$ al Istoriei universale, adecă de obște, care cuprinde în sine întîmplärile veacurilor vechi, întocmită prin Signior Milot, commembrum Academiei Frîncești din Lion (Buda, 1800).

\section{Deutsch-Walachische Sprachlehre}

\subsection{Obiective}

Deutsch-Walachische Sprachlehre nu este, așa cum s-ar putea înțelege din titlu, o gramatică comparativă germano-română, ci o gramatică a limbii române scrisă în limba germană; teoria gramaticală privește strict limba română, iar tuturor exemplelor românești li se indică echivalente în germană. Prin această lucrare, Molnar atinge cel puțin trei obiective importante: primul are în vedere normarea limbii române (prin fixarea unor reguli numeroase, clare, concise și bogat exemplificate); al doilea constă în punerea la dispoziția funcționarilor austrieci care activau în Transilvania și a negustorilor străini a unui manual de învăţare a limbii române. În al treilea rînd, prin introducerea capitolelor în care se oferă modele de enunțuri în limba română utilizabile în diverse situații de comunicare (la masă, la croitor, despre locuință, despre scriere, despre cumpărături, despre diferende juridice și fapte care prezintă pericol social, despre război, despre călătorii, despre atitudini specific umane, despre simptomele unor boli etc.), modele de cereri (pentru obținerea unui post „la canțelarie”, pentru scutirea de obligațiile de încartiruire etc.) și de scrisori (de recomandare, de condoleanțe, de felicitare etc.) se încearcă aducerea românei la un nivel la care să poată exprima, semantic și stilistic, aceleași conținuturi ca o limbă cultivată precum germana.

\subsection{Versiunile gramaticii}

Succesul de care lucrarea s-a bucurat în epocă explică cele trei ediții ${ }^{3}$ ale sale. Prima ediție, din 1788, este semnată „Johann Molnar, medic oculist regal în Marele Principat al Transilvaniei”; cum în 1791 Molnar a fost numit profesor de oftalmologie la Cluj, primind, ulterior (în 1792), titlul nobiliar „von Müllersheim”, în ediţia din 1810 titulatura deținută de autor este completată: „Johann Molnar v. Müllersheim, medic oculist regal în Marele Principat al Transilvaniei și profesor public de bolile ochiului la Universitatea din Cluj”. În a treia ediție, apărută postum, adjectivul fost precedă aceeași titulatură: „Johann Molnar v. Müllersheim, fost medic oculist regal în Marele Principat al Transilvaniei și profesor public de bolile ochiului la Universitatea din Cluj”. Cunoscut, în posteritate, ca Ioan Piuariu-Molnar, autorul își semnează lucrările, așa cum se poate observa, cu numele Molnar, echivalentul în limba maghiară al lui Piuariu, provenit din substantivul comun piuariu 'morar' (după cum Müller, din titlul nobiliar „,on Müllersheim”, este echivalentul în limba germană al aceluiaşi cuvînt).

Ediția din 1788 a apărut la Viena, „la Joseph Nobil von Kurzbek, tipograf cezaro-crăiesc, mare negustor şi comerciant de cărți”, iar ediţiile din 1810 și 1823, la Sibiu, în tipografia lui „Martin Hochmeister,

\footnotetext{
${ }^{1}$ Pentru ideea că Molnar nu este autorul sau traducătorul Retoricii apărute în 1798, a se vedea Ursu (2002, p. 332-346), unde se arată că Molnar este numai editorul textului respectiv, care reprezintă o traducere mai veche a manualului lui Francesco Scuffi, Arta retoricii, apărut la Veneția în 1681.

${ }^{2}$ Ursu (2002, p. 347-352) consideră că Molnar este și traducătorul cărții populare Viața lui Bertoldo și a lui Bertoldino, feciorul lui, dimpreunăși a lui Cacasino, nepotul lui, apărută anonim la Sibiu, în 1799.

${ }^{3}$ Ediția din 1788 poate fi consultată, de exemplu, la Österreichische Nationalbibliothek, Viena (cota: 38.H.21 [în format tipărit], MF 3195 [în format microfilm] sau la adresa http://data.onb.ac.at/rec/AC10132890 [în format digital]); ediția din 1810 se găsește la Biblioteca Academiei Române, Filiala Iași, în colecția „Carte veche și manuscris”, cu numărul de inventar 000097; ediția din 1823 se găsește la BCU Cluj-Napoca, în colecția „Bibliografie Românească Veche” (cota 1186).
} 
tipograf cezaro-crăiesc”. Pe lîngă funcțiile înalte pe care le-a deținut în stat (magistrat, senator, primar al oraşului Sibiu), Martin Hochmeister (junior) a fost un vestit tipograf și librar, membru (din 1789) în aceeași lojă masonică, a Sfintului Andrei, din care Molnar făcea parte din 1781 (și în care a obținut gradul de companion în 1783 și gradul de maestru în 1784). Este probabil ca lui Hochmeister jr. să i se datoreze publicarea, postumă, a celei de a treia ediții a gramaticii lui Molnar.

Față de prima ediție, în următoarele (în special în cea de a treia) se corectează unele cuvinte românești și mai ales germane (care anterior fuseseră scrise greșit) sau se înlocuiesc unele echivalente germane ale cuvintelor românești cu altele mai potrivite. O altă diferență constă în lipsa, în ediția a treia, a secvenței dedicatorii prin care Molnar îşi manifestă recunoștința față de binefăcătorul său, Georg Banffi von Losonz. De asemenea, față de primele două ediții, în următoarea este considerabil redusă prefaţa, în care autorul își exprimă convingerea cu privire la utilitatea unei astfel de gramatici, în condițiile în care „afacerile necesită” cunoașterea unei limbi vorbite intens ,în Transilvania, în Bucovina, în Banat și în parte și în Ungaria”.

\subsection{Structura}

Toate cele trei ediții ale gramaticii germano-române cuprind, în afara prefeței: o parte de ortografie (împărțită în trei capitole), o parte de morfologie (cu 19 capitole), o parte de sintaxă (cu patru capitole), o Culegere de cuvinte românești și germane, Nişte dialoguri, pentru a cuvînta despre multe feliuri de stări inainte, Nişte povestiri și capitolul Stil trebnicesc, cărţi și alte însămnări aseaminea. S-ar putea spune, în aceste condiții, că autorul a abordat gramatica în accepția curentă în epocă (de știință completă a limbii), înglobînd în lucrarea sa, din acest motiv, și alte secțiuni pe lîngă cele de morfologie și de sintaxă. Precizăm însă că în prefață se justifică astfel structura lucrării: „Avînd în vedere lipsa desăvîrșită a unui dicționar, această gramatică n-ar fi de mare folos dacă nu ar suplini întrucîtva și rolul unui lexicon. De aceea, anexelor, care de fapt nu își au locul în cadrul unei gramatici, să li se îngăduie prezența, măcar pînă vor apărea un dicționar românesc și un manual de limbă română”. Definindu-şi lucrarea ca „o încercare a unei introduceri populare, al cărei principal merit îl constituie caracterul complet și corectitudinea regulilor, precum și concizia expunerii”, autorul clarifică, totodată, motivul absenței unor „,cercetări etimologice mai profunde”, care „păreau mai degrabă a-și găsi locul într-o gramatică completă și erudită”.

\subsection{Particularități}

Două aspecte atrag imediat atenția, la o simplă răsfoire a gramaticii. Primul se referă la transcrierea, pentru cititorul german, a cuvintelor românești. Acestea sînt scrise mai întîi cu alfabet chirilic și apoi transcrise cu litere latine, în conformitate cu regulile fonetice ale ortografiei germane, autorul sperînd că „acest tip de prezentare a pronunției prin litere latine îl poate ghida întrucîtva pe iubitorul de limbă română”.

Al doilea aspect vizează terminologia gramaticală; deși gramatica este scrisă în limba germană, terminologia gramaticală folosită este latinească. Termenii latini fiind incluși în enunțurile în germană, se supun regulilor de recțiune ale acestei limbi; atunci cînd am tradus textul, am păstrat terminologia latinească, respectînd însă regimul cazual al limbii române. De exemplu, un titlu ca: Von den Conjugationibus Verborum Regularium devine în română Despreconjugationes verborum regularium (von construindu-se în germană cu dativul, iar despre, cu acuzativul, în română), Von dem Articulo defin i to des weiblichen Geschlechts devine în română Despre articulum definitum de genul feminin; Von der Bildung des Nominativi Pluralis aus dem Nominativo Singularis, în română, Despreformarea nominativi pluralis de lanominativum singularem etc.

\subsection{Modelele gramaticii}

Ideea că Molnar a avut ca model, pe care l-a urmat îndeaproape, gramatica lui Samuil Micu şi Gheorge Șincai, Elementa lingux daco-romane sive valachice (apărută la Viena, în 1780) este larg răspîndită în literatura de specialitate. Am constatat că, în cazul unor capitole ale gramaticii, se confirmă, în mod clar, influența acestui model. Există însă și capitole diferite de cele corespunzătoare din Elementa sau capitole care figurează doar în gramatica lui Molnar, nu și în cea a lui Micu și Șincai. Faptul se explică prin aceea 
că Molnar a urmat și modelul unor gramatici străine, care au avut în epocă un mare succes și o circulație intensă.

Parcurgînd mai multe gramatici din secolul al XVIII-lea, ne-am concentrat atenţia în special asupra celor destinate (ca și lucrarea lui Molnar) însușirii unei limbi străine; am consultat, astfel, gramatici ale limbilor: franceză, italiană, latină și maghiară, redactate, toate, în limba germană (cu scopul învăţării lor de către cititorii germani). Am putut observa că există un anumit tipar comun al acestor gramatici, în sensul că structura lor este asemănătoare: toate conțin capitole de ortografie, de morfologie, de sintaxă, de lexic și capitole care cuprind dialoguri, povestiri și modele de enunțuri de diferite tipuri. Analogii există și în interiorul capitolelor; în secțiunea de lexic, de exemplu, delimitările se stabilesc întotdeauna onomasiologic (Despre Dumnezeu, Despre lume, Despre pămînt, Despre locuință etc.), iar cîmpurile astfel obținute conțin multe elemente comune. Dintre toate gramaticile consultate, două ne-au atras în mod special atenția, pentru că, dincolo de tiparul comun, recognoscibil și în gramatica lui Molnar, pot fi observate şi alte aspecte comune cu aceasta. Este vorba de două gramatici ale limbii franceze redactate în germană și cu terminologie gramaticală latinească (la fel ca gramatica lui Molnar): lucrarea lui J.R. des Pepliers: Nouvelle et parfaite grammaire royale françoise et allemande. Neue und vollständige königliche französische Grammatik, bisher unter dem Nahmen des Herrn der Pepliers vielmals herausgegeben (am consultat versiunea apărută la Leipzig, în 1765, la Tipografia M.G. Weidmanns Erben und Reich), respectiv gramatica lui Hilmar Curas, Erleichterte und durch lange Erfahrung verbesserte französische Grammatik (am consultat versiunea apărută la Berlin, în 1759, la Tipografia lui Friedrich Nicolai).

Astfel de gramatici (cu tiraje mari pentru vremea respectivă și care au beneficiat de mai multe reeditări succesive), concepute pentru cititorii germani în vederea învățării unei limbi străine i-au fost, fără îndoială, utile lui Molnar, din mai multe motive. Un prim motiv se referă la corespondentele în limba germană ale cuvintelor; am semnalat, în analiza noastră, situațiile în care echivalentele germane indicate de Molnar pentru cuvintele românești sînt identice cu echivalentele germane indicate în gramatica lui Pepliers sau în cea a lui Curas pentru cuvintele din limba franceză. Un al doilea motiv se referă la organizarea internă propriu-zisă a capitolelor. În al treilea rînd, fiind scrise în limba germană și cu terminologie gramaticală în limba latină, astfel de lucrări i-au furnizat lui Molnar și modele de formulare propriu-zisă a enunțurilor. Comparînd textul original (în germană) al gramaticii lui Molnar cu textele în germană ale lui Pepliers și Curas, pot fi observate comentarii sau recomandări redate în formulări identice sau asemănătoare.

De asemenea, am consultat și gramatica limbii germane scrisă în limba latină de către Georgius Nagy, Elementa lingue germanice (Viena, 1775), pe care Ursu (2012, p. 27) a indicat-o ca model urmat de Samuil Micu și Gheorge Șincai pentru a alcătui Elementa lingua daco-romana sive valachica.

\section{Influența modelelor străine în capitolele de morfologie ale gramaticii lui Molnar}

Am urmărit mai departe, în studiul de față, modul în care s-a concretizat influența modelelor străine în secțiunea de morfologie a gramaticii lui Molnar, intitulată Despre cercetarea cuvintelor (Etymologia). Așa cum se obișnuia în epocă, Molnar folosește cuvîntul etimologie cu sensul 'morfologie'. În original, deci în limba germană, titlul este identic cu cel din gramatica lui Pepliers: Von der Wortforschung (De l'étymologie). În nouă din cele 19 capitole care compun partea de morfologie este vizibilă amprenta modelelor străine.

\subsection{Capitolul despre adjectiv}

În capitolul al IX-lea, Despre comparaţie (Compa ratio), se oferă informații cu privire la formarea, în clasa adjectivului, a comparativului de superioritate (cu ajutorul adverbului mai) și a superlativului (cu ajutorul adverbelor prea și foarte), de la gradul pozitiv. În interiorul acestui capitol este plasat și un „repertoriu al celor mai comune a d j e c t i v o r u m" ale limbii române. În afara adjectivelor, observăm în acest inventar, care conține peste 500 de cuvinte-titlu, ordonate alfabetic, și unele adverbe sau locuțiuni adverbiale (vitejaşte, creștinește, omeneşte, cu direptul, cu grabă, într-adins, geaba etc.). Dacă în Elementa nu există un astfel de „repertoriu” de adjective, în schimb gramatica lui Pepliers conține un cuprinzător Recueil des adjectifs les 
plus familiers \& les plus usités/Sammlung der gemeinsten und gebräuchlichsten Adjectiv or um (cu peste 800 de cuvinte-titlu), iar gramatica lui Curas, un Auszug der gebräuchlichsten Adjectivorum (cu peste 600 de cuvinte-titlu).

\subsection{Capitolul despre numeral}

Pe lîngă numeralele cardinale și ordinale, care sînt înregistrate și în Elementa, Molnar menționează în gramatica sa și următoarele tipuri: comparative (proportio nalia), distributive (distributiva), colective (collectiva). Aceleași nomina numeralia se găsesc și în gramaticile lui Pepliers și Curas: cardinalia, ordinalia, proportionalia, collectiva, distributiva. În plus, în gramaticalui Curas, ca și în cea a lui Molar, numeralele cardinale sînt numite și Hauptzahlen (adică „principale” $)$.

Numeri proportionales, numite și multi plicativi, sînt: de un feliu, îndoit, întreit, inpătrat, insutit, care au în germană echivalentele einfach, zweifach, dreifach, vierfach, hundertfach. Exact aceleași exemple în limba germană se găsesc la Curas, ca echivalente ale următoarelor numerale din limba franceză: simple, double, triple, quatruple, centuple. „În privința celorlalte”, adică atunci cînd nu există forme create de la numerale cardinale prin intermediul unui verb $(\hat{\imath} n+d o i>a$ indoi $>$ indoit etc.), în gramatica lui Molnar se indică forme ca: încă o dată pe atîta, noch einmal so viel; de șasă ori pe atîta, sechsmal so viel; de o sută de ori, hundertmal. În gramatica lui Curas, noch einmal so viel îi corespunde lui une fois autant, sechsmal mehr îi corespunde lui six fois davantage etc.

Nu meri distributivi sint: cîte unul, einzeln (în gramatica lui Curas, este echivalent pentru un à un), cîte doi, zwei und zwei (în gramatica lui Curas este echivalent pentru deux à deux) etc.

Nu me ri colle c ti v i sînt: o păreache, ein Paar (în gramatica lui Curas îi corespunde une paire), un tuțin, ein Dutzend (în gramatica lui Curas îi corespunde fr. une douzaine) etc.

\subsection{Capitolele despre verb}

Capitolele al XII-lea, al XIII-lea și al XIV-lea, consacrate clasei lexico-gramaticale a verbului, conțin modele de flexiune, mai întîi a verbelor auxiliare $a f ı$ și $a$ avea, apoi a unor v e r b o r u m r e g u $\mathrm{l}$ a r i u m aparținînd celor patru conjugări delimitate în funcție de sufixele gramaticale $-a,-e a,-e s ̦ i$ i $-i$ și a unor ve r b o r u m passivorum, reciprocum şi irregularium.

Tiparul flexionar din gramatica lui Molnar este identic cu cel din gramatica lui Pepliers, inclusiv în ceea ce privește terminologia gramaticală utilizată:

- indicativus modus (tempus præsens, præteritum imperfectum, præteritum perfectum simplex, præteritum perfectum compositum, præteritum plusquamperfectum I, præteritum plusquamperfectum II, futurum);

- imperativus modus;

- optativus șiconjunctivus modus(tempus præsens, præteritum imperfectum optativi, præteritum imperfectum conjunctivi, præteritum perfectum, praeteritum plusquamperfectum optativi, præteritum plusquamperfectum conjunctivi, futurum);

- infinitivus modus (præsens și præteritum perfectum);

- participium (præsens și futurum);

- supinum;

- gerundia.

În interiorul modului indicativ sînt înregistrate, sub denumirea p r $x$ te r i t u m plu s qu a m p e r fe ct u m I, formele de mai-mult-ca-perfect analitic alcătuite din perfectul compus al verbului $a f i$ și participiul verbului de conjugat: am fost avut, ai fost avut, au fost avut etc., cu echivalentele germane ich hatte gehabt, $d u$ hattest gehabt, er hatte gehabt etc. Doar la verbul auxiliar a fi formele de p r x t e r it u m pl u s qu a mperfectum I sînt alcătuite din imperfectul auxiliarului a fi și participiul trecut: eram fost etc.

\footnotetext{
${ }^{4}$ În latină, cardinalis, derivat de la cardo, -inis, are sensul 'principal, fundamental, esențial'.
} 
Formele sintetice de mai-mult-ca-perfect sînt înregistrate sub denumirea p r æ t e r i t u m pl u s q u a m p e r fe c t u m I I: avusăm sau avuseasăm, avusăşs sau avuseasăş, avusă sau avuseasă etc. (cu aceleaşi echivalente germane: ich hatte gehabt, du hattest gehabt, er hatte gehabt etc.).

În gramatica lui Pepliers, sub denumirea pr xte ri t u m plusqua m pe r fe ct u m I sînt înregistrate formele de tipul javois eu, tu avois eu, il avoit eu (cu echivalentele germane ich hatte gehabt, du hattest gehabt, er hatte gehabt etc.), iar sub denumirea p ræt e r i t u m plu squ a m p e r fe c t u m I I, cele de tipul jeus eu, tu eus eu, il eut eu (cu aceleași echivalente: ich hatte gehabt, du hattest gehabt, er hatte gehabt etc.).

Optativul fiind încadrat la conjunctiv, se vorbește de optativus și conjunctivus modus. Formele de condițional-optativ prezent-aş avea, tu ai avea, ar avea etc. (în gramatica lui Pepliers: jaurois, tu aurois, il auroit) - sînt înregistrate sub denumirea præterit u m i m perfect u m o p ta ti vi, diferite depræteritu m im perfectu m con ju nctivi: (de)vream avea, (de) vreai avea, (de) vrea avea etc. (în franceză: jeusse, tu eusses, il ềt etc.). Lui præteritum imperfectum optativi îi corespund în germană fie Konjunktiv II, Präsens (formele: ich hätte, du hättest, er hätte etc.), fie Konjunktiv II, Futur I (formele: ich würde haben, du würdest haben, er würde haben etc.); lui p r x t e r i t u m i m p e r fe c t u m conjunctivi îi corespunde în germană Konjunktiv II, Präsens: (wenn) ich hätte, (wenn) du hättest, (wenn) er hätte etc.

Formele de conjunctiv perfect figurează sub denumirea p r æ t e r i t u m p e r f e c t u m: să fiu avut, să fii avut, să fie avut etc. (în franceză: j’aye eu, tu ayes eu, il ait eu etc.). Echivalentul german este Konjunktiv I, Präteritum: ich habe gehabt, du habest gehabt, er habe gehabt etc.

Formele de tipul: voifi avut sau voififost avut, veifi avut sau veififost avut, va fi avut sau va fifost avut sînt considerate præteritu m plusqua m perfectum optativi (în franceză figurează, sub această denumire, formele de condițional-optativ perfect: jaurois eu, tu aurois eu, il auroit eu). Echivalentul lui præteritum plusqua mperfectum optativi în germană este fie Konjunktiv II, Präteritum (formele de tipul: ich hätte gehabt, du hättest gehabt, er hätte gehabt), fie Konjunktiv II, Futur II (formele de tipul ich würde gehabt haben, du würdest gehabt haben, er würde gehabt haben).

Condițional-optativul perfect (aş fi avut, ai fi avut, ar fi avut etc.) este numit præteritum plus qua m perfectum conjunctivi; formele înregistrate în gramatica lui Pepliers sub această denumire sînt cele de tipul: jeusse eu, tu eusses eu, il ềt eu (echivalentul german este Konjunktiv II, Präteritum: ich hätte gehabt, du hättest gehabt, er hätte gehabt etc.). In cazul unor verbe, sub denumirea p ræ t e r it u m plusquamperfectum conjunctivi nu se înregistrează forme de condițional perfect, ci de condițional mai-mult-ca-perfect (formate din condiționalul perfect al verbului a fi + participiul verbului de conjugat): aş fi fost arat etc.

Timpului viitor (f u t u r u m) al acestui mod-(de) voi avea, (de) vei avea, (de) va avea etc. (la Pepliers: j'aurai eu, tu auras eu, il aura eu etc.) -îi corespunde în germană Konjunktiv I, Futur I: (wenn) ich werde haben, (wenn) du wirst haben, (wenn) er wird haben etc.

Formelor indicate de Molnar la ge r u n di a: de a avea, întru a avea, pentru a avea și de Pepliers pentru franceză: d'avoir, en ayant, à avoir sau pour avoir le corespund în germană, în ambele gramatici: $z u$ haben, im Haben, um zu haben.

Față de gramatica lui Molnar, Elementa lui Micu și Șincai se diferențiază, în privința modelului de conjugare indicat, prin următoarele aspecte mai importante:

- imperativul are și un timp viitor (cu forme identice cu conjunctivul prezent: să laud, să lauzi, să laude etc.);

- modul conjunctiv are patru timpuri: prezentul, imperfectul (= condițional-optativul prezent), perfectul, mai-mult-ca-perfectul (= condițional-optativul perfect), față de cele șapte timpuri din gramatica lui Molnar;

- acest mod este numit doar c o n j u n c t i v u s (în denumire nu intră şi termenul optativus), deși optativul prezent este considerat conjunctiv imperfect, iar optativul perfect este considerat conjunctiv maimult-ca-perfect; 
- mai-mult-ca-perfectul sintetic, numit de Molnar præter it u m plus qua m pe rfectu m II, se numește în Elementa plus qua mperfectum absolutum;

- la infinitivul prezent se indică forma lungă (de tipul a laudare); modul infinitiv are și un timp viitor (a fi lăudător);

- la modul gerunziu se indică, în funcție de flectivele latinești, forme în di și dum (de lăudare, de lăudatîn latină, ad laudandum sau laudandi), respectiv în do (lăudînd —în latină, laudando);

- modul participiu are și un timp viitor (de tipul a fi lăudător).

Notăm și că Molnar alege, pentru fiecare conjugare, și verbe care cunosc pe parcursul flexiunii alternanțe fonetice, atrăgînd explicit atenția asupra acestora: a călca (pentru alternanțele $c / \check{c}$ : calc/calci și a/ă: calcăl călcăm etc.), a certa (pentru alternanțele e/ea: cert/ceartă și t/ț: cert/cerți etc.); de asemenea, în interiorul conjugării a IV-a, este prezentat un model complet de conjugare a verbelor care primesc, la unele moduri şi timpuri, sufixul flexionar - esc.

Așa cum procedează și Pepliers în gramatica sa, Molnar oferă și modele de conjugare a verbelor pasive, reciproce și neregulate. Î́n cazul verbelor numite pasive, se poate constata că este vorba, de fapt, de verbe reflexiv-pasive (mă văz 'sînt văzut', te vez 'ești văzut' etc.); echivalentele în limba germană sînt verbe la diateza pasivă (ich werde gesehen, du wirst gesehen etc.). Verbele reciproce, deși primesc înaintea lor pe mă sau pe te, primind, astfel „forma passivo r u m”, nu sînt, de fapt, pasive, ci neutre. Ca în Elementa, în categoria verbelor neregulate sînt încadrate cele iotacizate, adică „verba care se termină în $i u$ ”, „dar se pot termina și în $n$ " (p. 239).

Capitolul al XV-lea constă într-un inventar, ordonat alfabetic, „în care sînt prezentate probabil cele mai cunoscute verba”; sînt incluse aici peste 1200 de cuvinte-titlu. Un astfel de inventar nu se găsește în Elementa; la fiecare verb se indică și numărul conjugării căreia acesta îi aparține și echivalentul/ echivalentele în limba germană. Dintre gramaticile străine consultate, un bogat inventar în care verbele sînt grupate în funcție de conjugarea în care se încadrează conține gramatica lui Curas.

\subsection{Capitolul despre adverb}

La clasa adverbului, în partea introductivă se oferă, în formulări asemănătoare, informațiile din Elementa: adverbele pot fi primare sau derivate; acestea din urmă pot lua naștere fie de la adjective care au ca regent un verb sau un adjectiv, fie de la substantive; mai exact, de la forma de plural a acestora, prin înlocuirea desinenței de plural cu sufixul - esc, se formează mai întîi un adjectiv (de exemplu, de la substantivul domn, prin înlocuirea desinenței $-i$ din pluralul domni cu sufixul -esc se formează adjectivul domnesc) și apoi adverbul, cu sufixul -ește (domnește).

Clasele de adverbe sînt delimitate în continuare din punct de vedere semantic. Observăm clasificarea mai detaliată față de Elementa, unde sînt menționate și exemplificate următoarele categorii: I. adverbe care arată loc, II. adverbe care arată timp, III. adverbe de ordine, IV. adverbe interogative, V. adverbe dubitative, VI. alte adverbe de diferite feluri. În gramatica lui Nagy, clasele de adverbe sînt următoarele:
I. adverbia locum denotantia,
II. adverbia tempus significantia,
III. adverbia numerum denotantia,
IV. adverbia ordinis,
V. adverbia interrogandi,
VI. adverbia quantitatis,
VII. adverbia intendendi \& remittendi,
VIII. adverbia comparandi,
IX. adverbia congregandi,
X. adverbia separandi,
XI. adverbia limitantia,
XII. adverbia eligendi,
XIII. adverbia affirmandi, 
XIV. adverbia negandi,

XV. adverbia dubitandi,

XVI. adverbia hortandi.

La Molnar, adverbele sînt împărțite în nouă clase: adverbe de loc, adverbe de timp, adverbe de ordine, adverbe cantitative, adverbe calitative, adverbe de micșorare și de mărire, adverbe interogative, adverbe de negație și de afirmație, adverbe de alte tipuri.

Prima clasă, a adverbelor de loc, cuprinde adverbe care răspund la întrebarea unde?, adverbe care răspund la întrebarea încătrăo?, respectiv adverbe care răspund la întrebarea de unde?. Și ilustrarea acestor subclase urmează modelul din Elementa, care respectă modelul gramaticii lui Nagy; exemplele sînt numeroase (reprezentate de adverbe simple, compuse și locuțiuni adverbiale). Printre exemple observăm și cîteva locuțiuni prepoziționale (ca în preajma sau afară de). A doua clasă conține adverbele de timp; și aici cele mai multe exemple se regăsesc în gramatica lui Micu și Șincai.

Dintre adverbele de ordine indicate în Elementa, șase se regăsesc cu aceeași formă sau cu formă apropiată la Molnar: de nou, însă, întîiu, pe urmă (la Molnar: pre urmă), de aci (la Molnar: de aici), după aceea (la Molnar: după aceasta); în loc de tanda (din lat. tandem), Molnar îl indică pe spre sfîrşit (în germană endlich, zu Ende). De asemenea, față de Elementa, la Molnar lipsește încîlcit, dar se adaugă alte 24 de exemple. Corespondentele germane ale acestora nu apar în gramatica lui Nagy, dar le găsim la Curas. Astfel, atît la Curas, cît și la Molnar găsim următoarele adverbe de ordine din limba germană: nach allen (în franceză îi corespunde après tout), în română, după toate; haufenweise (în franceză, par troupes), în română, cu grămada; worauf (în franceză îi corespunde après quoi), în română, la care; von Haus zu Haus (în franceză, de maison en maison), în română, de casă în casă; von Wort zu Wort (în franceză, de mot en mot), în română, de cuvînt în cuvînt; zugleich (în franceză, ensemble), în română, dinpreună; überhaupt (în franceză, en gros), în română, preste tot; alles auf ein Mal (în franceză, tout à la fois), în română, totodată; gleich (în franceză, d'abord), în română, deloc; in Allen (în franceză, en tout), în română, intru toate; aufein Mal (în franceză, tout à la fois, tout d'un coup), în română, deodată. Notăm și că, în originalul german al lui Molnar, denumirea acestei clase este Nebenwörter der Ordnung. Adverbia ordinis, iar la Curas, Adverbia ordinis, der Ordnung.

Clasa adverbelor cantitative lipsește în Elementa. $\mathrm{O}$ astfel de clasă este delimitată în gramatica lui Curas, iar corespondentele germane date de Molnar pentru limba română sînt identice cu cele date de Curas pentru limba franceză: genug (în franceză îi corespunde assés), în română, destul; überflüßig (în franceză, abondamment), în română, de prisosit; halb und halb (în franceză, à demi), în română, de jumătate; viel (în franceză, beaucoup), în română, mult; wenig (în franceză, peu), în română, puțin; mehr (în franceză, d'avantage), în română, mai mult; viel größer (în franceză, beaucoupplus), în română, cu mult mai mare; viel weniger (în franceză, beaucoup moins), în română, cu mult maipuțin; nicht viel (în franceză, pas beaucoup), în română, nu mult; ganz (în franceză, entièrement), în română, întreg; aus Mangel (în franceză, faute de), în română, de lipsă; allgemach (în franceză, peu à peu), în română, pre încet; schier, fast (în franceză, presque), în română, mai; ganz und gar nicht (în franceză, point du tout, rien du tout), în română, nicidecît; nur (în franceză, seulement), în română, numai; genugsam (în franceză, sufisament), în română, din destul; zu viel (în francează, trop), în română, prea mult; so viel (în franceză, tant), în română, atîta; eben so viel (în francează, autant que), în română, tocma atîta; so viel als (în franceză, autant que), în română, atîta cît; zwei Mal so viel (în franceză, deux fois autant), în română, de doao ori atîta; gänzlich (în franceză, totalement), în română, de tot. Se adaugă două adverbe ale căror corespondente în limba germană nu se regăsesc în gramatica lui Curas: cu rîdicata, care are echivalentul german ballenweise, respectiv puțintel, cu echivalentul ein bischen. La Molnar, denumirea clasei este Nebenwörter der Menge. Adverbia Quantitatis, iar la Curas, Adverbia Quantitatis, einer Menge oder Mangels.

Pentru comparație, notăm că în gramatica lui Nagy sînt menționate următoarele adverbe cantitative: groß (în latină, magnum), lang (în latină, longe), ungeheuer (în latină, immane, prodigiose), dick (în latină, crasse), breit (în latină, late), viel (în latină, multum), mehr (în latină, plus), zu sehr (în latină, nimis, valde, admodum), gar (în latină, admodum, multum), sehr viel (în latină, valde multum), zuviel, allzuviel, 
garzuviel (în latină, nimium, nimis multum), überflüßig (în latină, abundanter), klein (în latină, paruum), kurz (în latină, breviter), dünn (în latină, subtiliter), schmal (în latină, arcte), schlank (în latină, graciliter), wenig (în latină, modicum), sehr wenig (în latină, valde modicum), nichts (în latină, nibil), gar nichts (în latină, plane nibil), ganz und gar nichts (în latină, penitus nibil), nur ein klein wenig (în latină, pauxillum tantummodo).

În Elementa nu există o clasă de adverbe calitative. Ca și în cazul adverbelor cantitative, la cele calitative corespondentele germane recomandate de Molnar sînt identice cu cele indicate de Curas pentru adverbele calitative ale limbii franceze. Astfel, corespondentele germane sînt: ungern (îi corespund à contre coeur în franceză și nebucuros în română); mit Willen (în franceză, à dessein, în română, cu voie); ernstlich/im Ernst (în franceză, tout de bon, în română, dinadins); mit Fleiß (în franceză, à dessein și exprès, în română, intr-adins); anders (în franceză, autrement, în română, altmintrilea); mit Güte/ in der Güte (în franceză, $\dot{a}$ l'amiable, în română, cu bine); unbewußt, obne (mein) Wissen (în franceză, à l'insu, în română, fără știre); inbrünstig (în franceză, passionement, în română, cu rîvnă); mit gutem Recht (în franceză, à bon droit, în română, cu direptate bună); flüchtig (în franceză, à la volée, în română, fluşturat); besonders (în franceză, à part, în română, mai vîrtos); mit Unrecht/ unrecht (în franceză, à tort, în română, nedirept); mündlich (în franceză, de bouche, în română, gură cu gură); beständig (în franceză, constamment, în română, statornic); schwerlich/beschwerlich (în franceză, mal-aisé, în română, cu greu); gern (în franceză, volontiers, în română, bucuros); von neuem (în franceză, de nouveau, în română, de nou); mit Recht (în franceză, de droit, în română, cu dirept); verkehrt (în franceză, travers, de travers, în română, întors); unbesonnen (în franceză, $\dot{a}$ l'étourdi și de but en blanc, în română, nebăgînd samă); unterschiedlich (în franceză, diversement, în română, de multe fealiuri); insbesondere (în franceză, en particulier, în română, deosebi); noch (în franceză, encore, în română, încă).

Se adaugă cîteva adverbe ale căror corespondente în limba germană nu se regăsesc în gramatica lui Curas: neplăcut (în germană, mißfällig), de demult (în germană, vorzeiten), în vreamea cea veche (în germană, vor alters), în vreamea cea trecută (în germană, in der vergangenen Zeit), de mijloc (în germană, mittelmäßig), fără veaste (în germană, unvermuthet). Notăm și că la Molnar această clasă de adverbe are, în textul german, denumirea Nebenwörter der Beschaffenheit. Adverbia Qualitatis, iar la Curas, Adverbia Qualitatis, der Beschaffenheit.

Următoarea clasă indicată de Molnar este cea a adverbelor de micşorare și de mărire (Nebenwörter der Nachlassung und der Vermehrung. Adverbia remissionis et intenssionis), clasă inexistentă în Elementa, dar pe care o găsim la Curas, sub denumirea Adverbia remissionis \& intensionis, der Nachlassung und Vermehrung. Și de această dată, în cazul celor mai multe adverbe, corespondentele germane indicate de Molnar coincid cu cele indicate de Curas: zusehends (în română, văzind cu ochi, în franceză, à vue d'oeil); unendlich (în română, nesfîrșit, în franceză, infiniment); Schritt vor Schritt (în română, pas de pas, în franceză, pas à pas); mittelmäßig (în română, de mijlóc, în franceză, mediocrement); zum wenigsten (în română, cît mai puțin, în franceză, au moins); nicht so viel (în română, nu atîta, în franceză, pas tant); kaum (în română, de-abia, în franceză, à peine); nach und nach (în română, pe încept, în franceză, peu à peu); so, sohin (în română, aşa, în franceză, là); desto beßer (în română, mai bine, în franceză, tant mieux).

În clasa interogativelor, cele mai multe adverbe sînt înregistrate și în Elementa: căci, dice (în Elementa, de ce), pentru ce, cît, cum, de cînd, cît de mare, de cîte ori, cît departe etc. Se adaugă cîteva adverbe al căror corespondent german este identic cu cel indicat de Curas pentru adverbele din limba franceză: pentru ce nu, cu echivalentul warum nicht (în franceză îi corespunde pourquoi pas); de unde, cu echivalentul woher (în franceză, d'où); cum dară, cu echivalentul wie denn (în franceză, comment donc); cum aşa, cu echivalentul wieso (das) (în franceză, comment cela). La Molnar, denumirea clasei este, în original, Fragende Nebenwörter. Adverbia interrogandi, la Curas: Adverbia interrogandi, des Fragens.

Clasa adverbelor de negație și de afirmație, clasă inexistentă în Elementa, conține elemente ale căror corespondente germane se găsesc, de asemenea, în gramatica lui Curas: în adevăr, cu echivalentul in der Wabrheit (în franceză îi corespunde à la vérité); cu adevărat, cu echivalentul gewißlich (în franceză, assurement și certainement); negreșit, cu echivalentul unfehlbar (în franceză, infailliblement și sans faute); 
pre credința mea, cu echivalentul auf meine Treue ${ }^{5}$ (în franceză, ma foi); nu am îndoială, cu echivalentul ich habe keinen Zweifel ${ }^{6}$ (în franceză, sans doute); bucuros, cu echivalentul gerne (în franceză, volontiers); într-adins, cu echivalentul im Ernst (în franceză, sincèrement); încă nu, cu echivalentul noch nicht (în franceză, encore pas, pas encore); nu așa curînd, cu echivalentul nicht so bald (în franceză, pas si tôt). Și de această dată, denumirea clasei este foarte apropiată de cea propusă de Curas: Nebenwörter der Verleugnung oder Bejahung. Adverbia affirmandi et negandi, față de Adverbia affirmandi \& negandi, der Bejahung oder Verneinung.

Ultima clasă conține, ca și cea corespunzătoare din Elementa, adverbe de alte tipuri; în ambele gramatici figurează adverbe și locuțiuni adverbiale ca numai, nimic (ca adverb, înv. și pop.) 'defel, deloc, nicidecum' (în Elementa, cu forma nemica), abia, anevoie, precum, măcar, aşadară, ca, încă, altmintrilea (în Elementa, amintrilea), de bună samă (în Elementa, de bună seamă), foarte, mai vîrtos, prea, adevărat, mai ales, bine, tocma, lesne, vez-bine (în Elementa, vezi-bine) etc. Observăm, în interiorul clasei, și conjuncții (precum deși, fiindcă) sau locuțiuni conjuncționale (măcar că, pentru că).

\subsection{Capitolul despre conjuncție}

În ceea ce privește conjuncțiile, dacă în capitolul corespunzător din Elementa este prezentată doar o listă care conține conjuncțiile uzuale ale limbii române (și echivalentele lor latinești), în gramatica lui Molnar se operează în schimb mai multe delimitări în interiorul acestei clase lexico-gramaticale. Modelul urmat este cel din gramatica lui Curas. Astfel, autorul are în vedere mai întîi asocierea cu modurile verbale, deosebindu-se conjuncții care se construiesc cu modul indicativ, cu modul conjunctiv, respectiv conjuncții care nu cer un anumit mod; la Curas: „Einige regieren (...) In d i c a t i v u m oder C o n j u n c t iv u m; einige regieren keinen Modum" (p. 294).

Se poate observa că echivalentele germane oferite de Curas pentru conjuncțiile din limba franceză coincid în mare măsură cu echivalentele germane din gramatica lui Molnar; faptul că Molnar ar fi putut pleca de la conjuncțiile din germană, cărora le-a identificat corespondente în limba română, explică eterogenitatea morfologică a exemplelor oferite de el; unele sînt conjuncții, dar altele aparțin altor clase lexico-gramaticale (cel mai frecvent, clasei adverbului).

Astfel, dacă urmărim corespondentele germane ale conjuncțiilor care se construiesc cu indicativul vom regăsi, și la Curas și la Molnar următoarele exemple comune: nachdem (în franceză îi corespunde selon que, în română, după cum); seitdem (în franceză îi corespunde depuis que, în română, de cînd); so oft (în franceză îi corespunde toutes les fois que, în română, de-atîtea ori); soviel (als) (în franceză îi corespunde autant que, în română, atîta cît); sobald (als) (în franceză îi corespund dès que sau d'abord que, în română, cîtva); so wie (în franceză, ḋ ce que, în română, precum); da (în franceză, lorsque, în română, cînd); als (în franceză, en même temps, în română, cînd); so lange, wie lange (în franceză, tant que, în română, pînă cînd). Corespondentul românesc al lui damit nicht (ca să $n u$ ) este încadrat în rîndul conjuncțiilor care se construiesc cu indicativul, în timp ce la Curas corespondentul lui damit nicht (în franceză, de crainte que, depeur que) figurează la conjuncțiile care se construiesc cu modul conjunctiv.

Și la conjuncțiile care se construiesc cu modul conjunctiv (la Curas, „die Co nju n c ti o n es, so den C o n j u n c tiv u m regieren”, p. 295) identificăm echivalente germane comune: im Fall daß (în franceză, en cas que, în română, des-ar); obwobl, obgleich (în franceză, bien que, quoique, encore que, în română, măcar că); ehe als (în franceză, avant que, în română, mai nainte de ce s-ar); daß (în franceză, que, în română, că); bis daß (în franceză, jusqu'à ce que, în română, pînă va); wenn gleich (în franceză, quand même, în română, măcar de nu).

Deși în gramatică nu se stabilește explicit o deosebire între conjuncțiile coordonatoare și conjuncțiile subordonatoare, putem observa că restricții de asociere cu modurile verbale sînt impuse de conjuncțiile subordonatoare, care conectează o propoziție subordonată de regentul ei la nivelul frazei; conjuncțiile

\footnotetext{
${ }^{5}$ La Curas: bey meiner Treu.

${ }^{6}$ La Curas: obne Zweifel.
} 
coordonatoare leagă două sau mai multe unităţi sintactice de aceeași importanță, la nivelul propoziției sau la nivelul frazei.

Prezentarea conjuncțiilor prezintă și mai departe asemănări cu gramatica lui Curas. Sînt enumerate conjuncțiile care nu cer un anumit mod; la Curas: „Folgende C o n ju n c ti o n e s regieren keinen Mo dum”: „1. Copulativa, die zusammen fügen, 2. Disjunctiva, die eine Rede aus einander setzen, 3. Adversativa, die einen Gegensatz der Rede anzeigen, 4. Cau sales, die eine Ursache anzeigen, 5. Exceptiva, wann man etwas ausnimmt, 6. Conclusiva, die einen Schluß machen" (p. 296-297). Aceleași sînt tipurile din gramatica lui Molnar.

Și în cazul conjuncțiilor copulative pot fi observate corespondente în limba germană care sînt indicate atît de Molnar, cît și de Curas; de exemplu, lui auch din germană îi corespund în română încă și în franceză aussi, lui nämlich îi corespond adecă în română și savoir que în franceză, lui nicht allein îi corespund nu numai în română și non seulement în franceză.

Corespondentele germane comune conjuncțiilor disjunctive din română, respectiv din franceză sînt: weder einer, noch der andere (în română, nici unul, nici altul, în franceză, ni l'un, ni l'autre); entweder, $\operatorname{oder~(în~română,~sau,~au,~în~franceză,~ou);~oder~aber~(în~română,~sau~măcar,~în~franceză,~ou~bien);~es~sey~(în~}$ română, să fie, în franceză, soit). Tot în categoria conjuncțiilor disjunctive sînt incluse aşadară (în germană, derobalben); nici (în germană, auch nicht); şi (în germană, und); ci (în germană, aberdoch) și altă dată (în germană, ein anders $M a l)$.

Și unele conjuncții adversative ale limbii germane enumerate de Curas se regăsesc la Molnar: hingegen (în română, dară, în franceză, en échange); aber (în română, dară, în franceză, mais); doch (în română, și tot, în franceză, mais); ungeachtet (în română, măcar că, în franceză, non obstant). În gramatica lui Molnar sînt incluse, de asemenea, în clasa adversativelor: pentru că (în germană, dieweil); fără numai (în germană, sondern nur); de nu (în germană, wenn nicht); altmintrilea (în germană, ansonsten); cît mai mare (în germană, je größer); findcă (în germană, indem, gleichwie); iară (în germană, wieder); de cumva (în germană, allenfalls, wenn, vielleicht). Dacă findcă și pentru că sînt încadrate la adversative, în schimb în categoria cauzalelor sînt înregistrate locuțiunea adverbială de cauză drept aceia și, de asemenea, ca să nu, cît nu, ca nu cumva, cu atît mai vîrtos.

La conjuncțiile cauzale identificăm, de asemenea, corespondente germane indicate și de Curas pentru limba franceză: damit nicht (în română, ca să nu și ca nu cumva, în franceză, afin de ne); um destomehr (în română, cu cît mai vîrtos, în franceză, d'autant plus que).

Ultimele două categorii sînt înregistrate ca adverbe de excepție (v o c e s e x c e p t i v ær), respectiv adverbe concluzive (conclusiva); corespondentului german ausgenommen îi corespund afară de în română și excepté în franceză, lui außer îi corespund afară în română și hormis în franceză, lui über dieses îi corespund preste aceasta în română și outre que în franceză, lui es sey denn îi corespund poate că să, respectiv à moins que. Tot astfel, la concluzive, lui also îi corespund precum, respectiv ainsi, lui endlich, mai pre urmă, respectiv enfin, lui dann, atunci, respectiv donc.

Notăm și că în gramatica lui Nagy conjuncțiile sînt clasificate după un singur criteriu, identificîndu-se douăsprezece clase sintactico-semantice: 1 . copulativæ, 2. cau sales, 3. cont in uat i væ, 4. co mparativæ, 5. disiunctivæ, 6. concessivæ, 7. adversativæ, 8. explanativæ, 9. conditionales, 10. consecutivæ, 11. conclusivæ, 12. intentionales.

\subsection{Capitolul despre interjecție}

Interjecțiile, „prin care se dă de înțeles o emoție sau un gînd” (p. 328), sînt împărțite în șapte clase. Apropierea de gramatica lui Curas poate fi observată chiar din denumirile acestora:

1. Zwischenwörter des Bittens und Ermahnens (la Curas: Interjectio, welche bittet und vermahnet);

2. Zwischenwörter, die eine Verwunderung anzeigen (la Curas: Interjectio, welche eine Verwunderung anzeiget);

3. Zwischenwörter des Mitleids (la Curas: Interjectio, welche ein Mitleiden anzeiget); 
4. Zwischenwörter, womit man an-und ausruffet (la Curas: Interjectio, womit man einen an-und zurufet);

5. Zwischenwörter der Danksagung (la Curas: Interjectio, womit man Dank saget);

6. Zwischenwörter, wodurch jemand auf die Seite zu gehen angewiesen wird (la Curas: Interjectio, womit man etwas an die Seite treibet);

7. Zwischenwörter, womit man etwas oder gar still zu schweigen verbiethet (la Curas: Interjectio, womit man etwas verbietet oder still zu schweigen).

În toate aceste șapte clase delimitate se observă și cuvinte sau expresii care, folosite interogativ-exclamativ, pot avea valoare de interjecții care indică surpriza, mirarea, neîncrederea, compasiunea, mulțumirea etc.: de exemplu, pronumele $c e$ avînd valoare de interjecție cu sensul 'cum adică?! se poate?!', adverbul afară avînd valoare de interjecție cu sensul 'ieși!, pleacă!', verbele la imperativ lasă(-mă), taci etc.

Clasa interjecțiilor de rugăminte și îndemn conține trei elemente: $o$, de (interjecția $o$ urmată de conjuncția de), o, de ar (se adaugă auxiliarul de persoana a III-a al condiționalului), ambele avînd corespondentul german $o$, wenn; a treia interjecție este fui, cu echivalentul german $p$ fui.

Mai multe interjecții „care arată o mirare” au aceleași corespondente germane precum cele indicate de Curas pentru limba franceză: großer Gott (căruia îi corespunde în franceză grand Dieu) are în română echivalentul mare Dumnezeu; tot astfel, lui wieso îi corespund, în franceză, comment, iar în română, cum așa; lui was - quoi în franceză și ce în română; lui $o$, Gott îi corespund, în franceză, $o$, Dieu și, în română, oh, Dumnezeule; lui vortreflich - admirable în franceză și prea bine în română; ist es möglich? are corespondentele est-il possible? în franceză și iaste cu putințăa în română; ach, wie schön! are corespondentele que cela est beau! în franceză și ah, cîtu-i de frumos! în română; es ist nicht möglich are echivalentele il n'est pas possible în franceză și nu-i cu putință în română; se adaugă, în această categorie, oh, Doamne și lasă-mă, cu echivalentele germane $o$, Herr și lasse mich, pe care nu le regăsim în gramatica lui Curas.

Interjecțiile care exprimă compasiune sînt $o$, vai; vai; și vai de mine, avînd corespondentele germane $o$, wehe; wehe (pe care le regăsim la Curas și la Nagy ca echivalente ale interjecțiilor din franceză, respectiv din latină).

La interjecțiile care exprimă o chemare/ o exclamare au corespondent identic sau asemănător cu cel indicat de Curas: hei, copile (în germană, he, du Junge), la arme (în germană, zum Gewehr), spre ajutoriu (în germană, zu Hilfe).

La cele două interjecții care exprimă mulțumirea (laudă lui Dumnezeu și mulțam lui Dumnezeu) ambele corespondente germane (gottlob, Gott sey Dank) figurează și în gramatica lui Curas în calitate de corespondente ale interjecțiilor din franceză (Dieu merci, graces à Dieu).

Menționăm și că în Elementa capitolul despre interjecții conține doar o scurtă listă de exemple (este vorba de interjecțiile o de!, aha!, vai!, ob!, oh, vai!, odată cu innima!, cară-te! și măi!). În gramatica lui Nagy interjecțiile limbii germane sînt împărțite în următoarele clase: 1. hor tant is, 2. i u bi la n ti s, 3 . dolentis, 4. optantis, 5. abominantis, 6. minantis, 7. iurantis.

\section{Receptarea gramaticii lui Molnar}

Gramatică practică și, totodată, manual de învățare a românei, Deutsch-Walachische Sprachlehre este una din ipostazele efortului depus de Molnar pentru normarea și cultivarea limbii. Succesul de care s-a bucurat gramatica poate fi dovedit nu doar prin cele trei ediții ale sale, ci și prin receptarea ei ulterioară. DeutschWalachische Sprachlehre a servit ca model pentru alte gramatici ale limbii române; unele dintre acestea au preluat ca atare fragmente substanțiale din lucrarea lui Molnar: cea a lui Anton de Marki, Auszug aus der für Normal-und Hauptschulen vorgeschriebenen deutschen Sprachlehre in deutscher und wallachischer Sprache, Cernăuți, 1810 și cea a lui Teoctist Blajevici (Theoktist Blazewicz), Theoretisch-praktische Grammatik der dacoromanischen, das ist: der moldauischen oder wallachischen Sprache [...], Lvov, 1844. Teoctist Blajevici, care va deveni în 1877 mitropolit al Bucovinei și al Dalmației, a publicat, sub numele Teoctist 
Șoimul (Theoktist Schoimul), alte două ediții ale gramaticii sale, cu titlurile: Theoretisch-praktische Taschengrammatik zur leichten und schnellen Erlernung der romanischen (walachischen) Sprache, Wien, 1855, respectiv Kurzgefasste praktische Grammatik der romanischen (walachischen) Sprache: Mit einem praktischen Theile, enthaltend die im Umgange nothwendigsten Wörter, Gespräche, Sprichwörter, Briefe, Lese-und Uebersetzungsübungen, nebst einem Wortverzeichnisse, Zweite Auflage, Wien und Hermannstadt, 1866.

O altă gramatică influențată de Deutsch-Walachische Sprachlehre este cea intitulată Walachische Sprachlebre für Deutsche, nebst einem kleinen Walachisch-Deutsch und Deutsch-Walachischen Handwörterbuche, Buda, 1823 (ediția a II-a, 1836), al cărei autor, Andreas Clemens, menționează în prefața primei ediții (p. 4) că „volumul domnului von Müllersheim (...) se află în mîinile multor iubitori ai limbii române”.

După ce publicaţia „Wiener Zeitung” semnalează, în numărul 52 din 28 iunie 1788 (p. 1608), printre cărțile nou-apărute în librăriile vieneze, gramatica lui Molnar, aceasta beneficiază, la un an de la apariție, de o recenzie în prestigioasa publicație „Allgemeine Literatur-Zeitung”, Jena/ Halle, 1789, vol. 2, nr. 177, din iunie, p. 606-607; volumul este descris aici ca „primul îndrumar cu adevărat folositor cu privire la [...] la limba română” (în original, „Ungeachtet des häufigen Gebrauchs der Wallachischenn Sprache, auch durch die ganze Moldau, in Siebenbürgen, dem Banat u.s.w. ist dieses die erste recht brauchbare Anleitung dazu" [p. 606]). Ediția a doua a gramaticii a fost prezentată în „Wiener Allgemeine Literatur-Zeitung” (nr. 56 din 13 iulie 1810, p. 895-896). Menționăm că în presa vremii sînt consemnate, de asemenea, operațiile de succes efectuate de medicul Molnar la Viena și la Bratislava (în „Wiener Zeitung”, nr. 78 din 28 septembrie 1785, respectiv în nr. 20 din 8 martie 1788, p. 573), ca și conferirea titlului nobiliar von Müllersheim (în „Wiener Zeitung” nr. 69 din 25 august 1792, p. 2346).

În ceea ce privește mențiunile despre gramatica lui Molnar, notăm că Gheorghe Șincai, în prefața celei de a doua ediții din Elementa lingue daco-romane sive valachice (Buda, 1805), precizează că, „după opt ani” de la prima ediție (din 1780), pe care a elaborat-o împreună cu Samuil Micu, „adică în anul 1788, aceeași gramatică a noastră, revizuind-o și completînd-o, a tipărit-o la Viena, în limbile germană și română, strălucitul domn Ioan Molnar de Müllersheim” (p. 4). Lucrarea este semnalată și de István Horvát, în Rajzolatok a Magyar Nemzet legrégiebb történeteiböl, apărută la Editura Mátyás Petrózai Trattner, Pesta, 1825.

Mărturii cu privire la gramatica lui Molnar aduce şi Bogdan Petriceicu Hasdeu, atît în Cuvente den bătrîni, Tipografia Societății Academice Române, Bucureşti, 1878-1881, cît și într-o scrisoare către Hugo Schuchardt, din data de 27 octombrie 1878 (al cărei original se află în Colecția Schuchardt din Arhiva Universității din Graz), în care se fac observații referitoare la verbul aciiu.

Conțin, de asemenea, referiri la gramatica lui Molnar diverse studii care, de-a lungul timpului, au abordat diacronic fie limba literară (Werner Bahner, Das Sprach-und Geschichtsbewußtsein in der rumänischen Literatur von 1780 bis 1880, Akademie-Verlag, Berlin, 1967; Jürgen Erfurt, Bildungswesen und Sprachgeschichte: Südostromania, în Gerhard Ernst, Martin-Dietrich Gleßgen, Christian Schmitt, Wolfgang Schweickhard (editori), Romanische Sprachgeschichte / Histoire linguistique de la Romania. Ein internationales Handbuch zur Geschichte der romanischen Sprachen, 2. Teilband, De Gruyter, Berlin, 2006, p. 1203-1213; Wolfgang Dahmen, Magyarisierungsversuche im Siebenbürgen des 19. Jahrhunderts als Motor für die Sprachnormierung des Rumänischen, în Wolfgang Dahmen, Werner Schlösser (editori), Sexaginta. Festschrift für Johannes Kramer, Helmut Buske Verlag, Hamburg, 2007, p. 97-111), fie contactele dintre limbi (Jon Borcia, Deutsche Sprachelemente im Rumänischen, teză de doctorat la Universitatea din Leipzig, 1903), fie didactica limbii (Michael Metzeltin și Petrea Lindenbauer, Terminologie und allgemeiner Wortschatz im Spiegel didaktischer Grammatiken. Ein rumänisches Beispiel, în Günter Holtus, Johannes Kramer, Wolfgang Schweickard (editori), Italica et Romanica. Festschrift für Max Pfister zum 65. Geburtstag, Niemeyer, Tübingen, 1997), fie sistemele de scriere (Sebastian Kempgen, Slavic Alphabet Tables, University of Bamberg Press, Bamberg, 2016), fie terminologia medicală (V. Bologa, Terminologia medicală românească a doctorului Ioan Piuariu (Molnár von Müllersheim), în „Dacoromania”, IV (1), 1924-1926, p. 383-393; V. Bologa, I. Spielmann, Z. Szőkefalvi Nagy, Date noi cu privire la activitatea lui Ioan Piuariu-Molnar, în „Revista Medicală”, nr. 15/1970, p. 501-507; Teodora Daniela Sechel, Medical 
knowledge and the improvement of vernacular languages in the Habsburg Monarchy: A case study from Transylvania (1770-1830), în "Studies in History and Philosophy of Biological and Biomedical Sciences”, nr. 3, 2012, p. 720-729 ș.a.).

\section{Concluzii}

Raliindu-se preocupărilor epocii, Molnar s-a alăturat, de fapt, unui țel și unor exigențe pe care cărturarii ardeleni, cu un scrupul tenace al datoriei, și le-au autoimpus și pe care nu le-ar fi putut îndeplini decît printr-o moblizare comună, printr-o suită de eforturi și de acțiuni. $\mathrm{Cu}$ intelectualii ardeleni contemporani cu el, autorul gramaticii germano-române împărtășește și respectul pentru autoritatea rațiunii și pentru rigoarea științei, curiozitatea intelectuală, spiritul polemic și hărnicia neobosită. Și tot ca în cazul lor, acestor calități li s-a adăugat dimensiunea vocației: atît în profesia de medic, în care a ajuns la un nivel de recunoaștere și la performanțe remarcabile (în 1780 a fost solicitat la Viena, de către feldmareșalul Petru de Gourcy, pentru a-l opera de cataractă la ambii ochi; dintr-un raport întocmit de Molnar rezultă că în 1786 a vindecat 101 cazuri [Lupaș, 1939, p. 25] etc.), cît și în manifestările publice care vizau cultivarea și modernizarea limbii și a societății.

\section{Bibliografie}

Elementa $=$ Samuil Micu, Gheorghe Șincai, Elementa lingue daco-romane sive valachica, studiu introductiv, traducerea textelor și note de Mircea Zdrenghea, Editura Dacia, Cluj-Napoca, 1980.

Lupaș, I. (1939). Doctorul Ioan Piuariu-Molnar: viața și opera lui, Imprimeria Națională, București.

Niculescu, Al. (1978). Individualitatea limbii române între limbile romanice, vol. II. Contribuții socioculturale, Editura Științifică şi Enciclopedică, București.

Ursu, N.A. (2002). Contribuții la istoria culturii românești. Studii și note fllologice, Editura Cronica, Iași.

Ursu, N.A. (2012). Alte contribuţii la istoria culturii româneşti. Studii și note filologice, Editura Cronica, Iași. 